Federal Reserve Bank of Dallas

Globalization and Monetary Policy Institute

Working Paper No. 13

http://www.dallasfed.org/assets/documents/institute/wpapers/2008/0013.pdf

\title{
Globalisation, Domestic Inflation and Global Output Gaps: Evidence from the Euro Area*
}

\author{
Alessandro Calza \\ European Central Bank
}

May 2008

\begin{abstract}
This paper tests whether the proposition that globalisation has led to greater sensitivity of domestic inflation to the global output gap (the "global output gap hypothesis") holds for the euro area. The empirical analysis uses quarterly data over the period 1979-2003. Measures of the global output gap using two different weighting schemes (based on PPPs and trade data) are considered. We find little evidence that global capacity constraints have either explanatory or predictive power for domestic consumer price inflation in the euro area. Based on these findings, the prescription that central banks should specifically react to developments in global output gaps does not seem to be justified for the euro area.
\end{abstract}

JEL codes: E3, F4

\footnotetext{
* Alessandro Calza, European Central Bank, European Central Bank, Kaiserstrasse 29, 60311 Frankfurt am Main, Germany. alessandro.calza@ecb.europa.eu. +49-69-1344-6356. I am very grateful to Stephane Dees and Filippo di Mauro for kindly sharing the dataset of their study and to Benoît Mojon, Warwick McKibbin and an anonymous referee for a number of helpful suggestions. The views in this paper are those of the author and do not necessarily reflect the views of the European Central Bank, the Federal Reserve Bank of Dallas or the Federal Reserve System.
} 


\section{Introduction}

In recent years, many industrialised economies have experienced low and stable inflation, despite a combination of developments, such as declining slack in product and factor markets, protracted monetary and fiscal policy accommodation and rising commodity and industrial raw material prices, that the experience of the late 1960s and the 1970s had led us to associate with the emergence of inflationary pressures. This unusual combination of events has given rise to the question whether the traditional linkages over the business cycle between inflation and its domestic determinants may have weakened over the past two decades.

As evidence of structural changes in the inflation process, various studies have reported estimates of aggregate supply equations or "Phillips curves", showing that the impact of measures of domestic capacity constraints on inflation has declined over time and, in some cases, become insignificant. ${ }^{1}$ In professional jargon, it is customary to refer to these empirical findings as evidence that the Phillips curves have "flattened".

Several scholars and policy makers have recently argued that globalisation can contribute to explaining the reduced responsiveness of inflation to capacity constraints at home. ${ }^{2}$ For instance, BIS (2005, p. 20) notes that "Increased globalisation could well mean that domestic factors have become less of a determinant of inflation in individual countries." In a similar vein, Helbling et al. (2006) argue that "Globalization has contributed to reducing the sensitivity of inflation to domestic capacity constraints in advanced economies over the past couple of decades [...]".

Trade openness, international competition in factor markets and financial integration are among the main channels through which globalisation is believed to have reduced the sensitivity of inflation to domestic capacity constraints.

Interestingly, from the proposition that domestic macroeconomic con-

\footnotetext{
${ }^{1}$ See for instance Roberts (2006), Helbling et al. (2005) and Pain et al. (2006).

${ }^{2}$ Recent contributions include BIS (2005), Fisher (2005), Greenspan (2005), Helbling et al. (2006) and Borio and Filardo (2007). Additional explanations of why inflation may have become less responsive to domestic macroeconomic conditions include increased commitment to price stability by central banks, liberalisation and deregulation of product markets, structural reforms of labour markets (particularly, the introduction of more flexible wage-setting mechanisms) and productivity growth reflecting advances in the IT industry.
} 
ditions now matter less for inflation, some authors have derived the corollary that monetary policy-makers aiming to maintain price stability should pay closer attention to measures of global capacity utilisation (see e.g. Fisher, 2005). This prescription has become increasingly popular with the press. Thus, The Economist (2005) argues that "[...] in forecasting inflation central banks now need to pay less attention to domestic shifts in unemployment and capacity utilisation and much more to the global balance between supply and demand.", while Business Week (2006) dramatically concludes that "[...] the era of a purely domestic monetary policy is over."

More generally, it has been argued that traditional models of the inflation process that mainly focus on domestic determinants (though they may also allow for external influences through import prices, exchange rates, etc.) have become less relevant in globalised economies. The results of a study by Ciccarelli and Mojon (2005) arguing that in industrialised countries inflation has become a "global" phenomenon have been interpreted as providing some support to this view. ${ }^{3}$ In addition, Dees et al. (2007) find that foreign inflation has a statistically significant impact on domestic inflation in some economies.

The hypothesis that domestic inflation has become sensitive to foreign cyclical conditions (the so-called "global output gap hypothesis") has important implications for the formulation of monetary policy, which certainly explains why a number of policy-makers have recently taken an interest in it (see for instance Kohn, 2005, 2006, Papademos, 2006, Yellen, 2006, González-Páramo, 2007, and Bernanke, 2007). In particular, one question often raised by policy-makers is whether an increased dependence of inflation on global conditions, to the detriment of its traditional domestic influences, may undermine the ability of national central banks to control the dynamics of inflation. Under this scenario, central bankers may be forced to change the way they conduct monetary policy, possibly by relinquishing their autonomy in favour of some mechanism of coordination among national policies.

\footnotetext{
${ }^{3}$ To illustrate their argument, the authors compute various measures of global inflation and show that, on average, these measures can explain around $70 \%$ of the variance of inflation in a large sample of OECD countries.
} 
Given the implications for monetary policy formulation, the globalisation hypothesis should be subjected to more thorough conceptual and empirical analysis. Indeed, its conceptual foundations have been recently challenged by Ball (2006) and Woodford (2007). In particular, Ball (2006) argues that the hypothesis that globalisation can systematically affect the overall inflation rate is due to the failure to distinguish between changes in the relative prices of goods and services and those in the general price level, which are determined in the long run by monetary policy. Thus, if the central bank's inflation objective is held constant, declines in the relative prices of imported goods due to globalisation will be eventually offset by rises in those of domestically-produced goods and services. While acknowledging that large shocks to relative prices could, under certain assumptions regarding nominal rigidities, lead to protracted changes in the overall inflation rate, Ball (2006) notes that the changes in relative prices induced by globalisation have been too small and smooth to meet those conditions. ${ }^{4}$ More generally, Woodford (2007) analyses the implications of globalisation in financial, final goods and factor markets for monetary policy in the context of a canonical new Keynesian model. He concludes that, even under the assumption of significantly more complete global integration than experienced in practice, national central bankers are unlikely to lose the ability to control the dynamics of inflation.

As regards the empirical evidence on the globalisation hypothesis, it is fairly mixed, possibly reflecting to some extent the uncertainty surrounding global output gap measures. ${ }^{5}$ Most existing studies focus on the US: Garner (1994), Orr (1994), Tootell (1998) and Ihrig et al. (2007) find that excess foreign capacity has little or no effect on US domestic inflation; by contrast, Gamber and Hung (2001) and Borio and Filardo (2007) obtain the opposite result, with Wynne and Kersting (2007) also reporting evidence of a positive correlation between the cyclical component of US inflation and the global output gap. The evidence for other coun-

\footnotetext{
${ }^{4}$ Ball (2006) also notes that output gaps are empirical proxies for marginal costs and notes that, while globalisation may have reduced average domestic markups, it is doubtful that it can have affected the cyclical relationship between marginal costs and the domestic output level.

${ }^{5}$ See Wynne and Solomon (2007) for a discussion of the various challenges implied by the calculation of global production capacity and slack.
} 
tries is equally ambiguous: Borio and Filardo (2007) estimate Phillips curves for fifteen industrialised countries and find that in most of these economies the addition of global capacity measures significantly increases the explanatory power of the models. ${ }^{6}$ However, their results have been challenged by Ihrig et al. (2007) and Ball (2006), who perform similar empirical analyses for a slightly narrower sample of countries, and by Pain et al. (2006) using a system of error correction models for a sample of 21 OECD economies. ${ }^{7}$

The only empirical evidence available for the euro area is that provided by Borio and Filardo (2007) and appears rather weak. Based on estimated Phillips curves, the authors find that the global output gap influences euro area inflation. However, their results are not robust to the inclusion of additional explanatory variables (e.g. changes in oil and import prices) in the equations.

The purpose of this paper is to provide fresh empirical evidence on the information content of foreign output gaps on contemporaneous and future domestic consumer price inflation in the euro area. The empirical analysis is based on data spanning the 1979-2003 period and consists of: (1) the estimation of alternative specifications of Phillips curves augmented by the contemporaneous foreign output gap (as in Tootell, 1998); and (2) an assessment of the leading indicator properties of global cyclical conditions for domestic inflation based on Hamilton and Kim (2002). To preview our results, we find little evidence in support of the hypothesis that global output gaps have either explanatory or predictive power for euro area inflation.

\section{Data issues}

The empirical analysis is based on quarterly data on consumer prices and real GDP for 26 advanced and developing economies (the euro area plus 25 individual countries) covering the large majority of world output,

\footnotetext{
${ }^{6}$ Borio and Filardo (2007) choose a non-standard measure of inflationary pressures, given by the deviation of annual headline consumer price inflation from the trend in annual core inflation (i.e. excluding food and energy) obtained with a Hodrick-Prescott filter.

${ }^{7}$ Ball (2006) and Pain et al. (2006) also include the US in their samples.
} 
over the sample period 1979:2-2003:4. ${ }^{8}$ The data on the euro area are sourced from Fagan et al.'s (2005) Area Wide Model, that on the foreign countries from Dees et al.'s (2007) global VAR model. In order to test the robustness of the results, in some of the regressions we also include quarterly changes in $p_{i t}^{o}$, a logarithmic index of US-dollar denominated oil prices converted into euro at market exchange rates.

Foreign output is computed by aggregating data on the 25 foreign economies using two alternative sets of weights: (1) trade weights derived from bilateral trade statistics and (2) weights based on Purchasing Power Parities (PPPs).

Trade weights are computed as in Dees et al. (2007) and Pesaran et al. (2004) and can be interpreted as measures of "economic" distance. The choice of trade weights to compute foreign aggregates is supported by studies on business cycle synchronisation - e.g. Baxter and Kouparitsas (2005) and Forbes and Chinn (2004) - showing that bilateral trade represents the main source of international linkages. The use of PPPs (sourced from the IMF) to compute country weights has a long tradition in studies on international comparisons of nominal outputs and incomes, which often argue that, by adjusting for differences in national price levels, PPP-based estimates of country weights provide more appropriate measures of the share of each country in global output. ${ }^{9}$

More specifically, considering the euro area as the domestic economy and 25 foreign economies indexed by $j=1, \ldots, 25$, the global output $Y_{t}^{f}$ is defined as the weighted average of real GDP $Y_{j t}$ over the foreign economies:

$$
Y_{t}^{f}=\sum_{j=1}^{25} w_{j} Y_{j t},
$$

In the case of trade weights, $w_{j}$ is given by the average share of country $j$ in the exports and imports of the euro area over the period 1999-2001. ${ }^{10}$

\footnotetext{
${ }^{8}$ The foreign countries covered are Argentina, Australia, Brazil, Canada, Chile, China, India, Indonesia, Japan, Malaysia, Mexico, New Zealand, Norway, Peru, Philippines, Saudi Arabia, Singapore, South Africa, South Korea, Sweden, Switzerland, Thailand, Turkey, United Kingdom and the United States.

${ }^{9}$ For a discussion see Gulde and Schulze-Ghattas (1993).

${ }^{10}$ The trade data used for the computation of the trade-based weights are sourced from
} 
Under the alternative PPP-based weighting scheme, $w_{j}$ is given by the share of country $j$ in the aggregate value of GDP (converted into a common currency using 2005 PPPs) of the foreign countries considered. It should be noted that previous studies of the effect of foreign capacity constraints on inflation have used both trade-based and PPP-based weights.

The output gaps are defined as the deviations of real GDP from their potential levels, with those levels estimated using the Hodrick-Prescott filter. In the case of the foreign variables, the Hodrick-Prescott filter is applied directly to the aggregate data on foreign output. ${ }^{11}$ As suggested by Kaiser and Maravall (1999), in order to mitigate the well-known endof-sample problem of the Hodrick-Prescott filtering procedure, the output series are preliminarily extended by eight quarters by means of forecasts using ARIMA models (specified and estimated using the econometric package Tramo).

For illustrative purposes, Figure 1 shows both the euro area output gap and the global output gaps computed under the two alternative weighting schemes. While the developments in the euro area and foreign output gaps were relatively synchronised in the late 1970s and early 1980 s, they significantly differed throughout the second half of the 1980s and most of the 1990s. However, the differences in developments became less pronounced towards the end of the 1990s and at the start of this decade. The global output gaps computed under both trade and PPP weights behave similarly over most of the sample period, though there are periods (e.g. the mid-1980s and early 1990s) during which the differences between the two series are non-negligible.

\section{Empirical analysis}

As a preliminary analysis of the relationship between euro area inflation and global cyclical conditions, Table 1 reports the share of the variance of headline consumer price inflation in the euro area that is explained

\footnotetext{
Direction of Trade Statistics, 1999-2001, IMF. For more details, see Dees et al. (2007).

${ }^{11} \mathrm{An}$ indirect approach, followed for instance by Tootell (1998), consists of first computing the individual output gaps of the country's main trading partners and then aggregating them using trade weights.
} 
by the global output gaps (as a benchmark, we also include the share of variance accounted for by the domestic output gap). ${ }^{12}$

Regardless of the weighting scheme used, the share of headline inflation variance explained by the foreign output gap over the full sample 1979:1-2003:4 is nil. One potential explanation may be the difficulty for the stationary global output gaps to account for the trending behavior of inflation during the 1980s (see Figure 2). If so, a simple way of addressing this problem would be to compute the statistic over a sample starting at a later point in time, possibly when the downward trend in inflation has become less pronounced. Based on a purely visual inspection, we somewhat arbitrarily pick the end of 1985 as the starting point for the new sample period. While the share of headline inflation variance explained by the domestic output gap increases significantly, those of the foreign output gaps under both PPP- and trade-weights remain negligible.

An alternative approach consisting of removing in advance the trend in inflation by means of a statistical filter does not lead to a rise in the capacity of the global output gaps to account for inflation variance over either sample period (see Table 1).

This simple analysis suggests that it may be difficult to find evidence of a systematic influence of foreign cyclical conditions on euro area inflation. However, since the statistical indicators reported in Table 1 can be no substitute for a model-based analysis that takes additional determinants of inflation into account, the following section presents such analysis.

\subsection{Phillips curves augmented by global output gaps}

Following Tootell (1998) we analyse the effect of foreign cyclical activity on domestic inflation in the modelling framework of Phillips curves augmented by foreign output gaps. While this is an admittedly simple framework that cannot fully capture all the channels through which the global cycle affects domestic prices, it may nevertheless shed light on its impact elasticity for euro area inflation.

\footnotetext{
${ }^{12}$ The share of variance is equivalent to the $\mathrm{R}^{2}$ of a regression of euro area inflation on the global output gap (with a constant term in the equation).
} 


\subsubsection{Backward-looking Phillips curves as in Rudebusch and Svens- son $(1999,2002)$}

More precisely, we consider an augmented version of the backward-looking specification of the Phillips curve model used in Rudebusch and Svensson (1999, 2002):

$$
\boldsymbol{\pi}_{t+1}=c+\sum_{j=0}^{3} \alpha_{\pi j} \boldsymbol{\pi}_{t-j}+\beta y_{t}^{h}+\gamma y_{t}^{f}+\varepsilon_{t+1}
$$

with $\boldsymbol{\pi}_{t+1}=4 \cdot\left(p_{t+1}-p_{t}\right)$ denoting the annualised quarterly inflation rate (with $p_{t}$ the consumer price index in natural $\operatorname{logs}$ ), $y_{t}^{h}$ the domestic output gap and $y_{t}^{f}$ the global output gap. The equation relates the inflation rate to its lag values and measures of the domestic and foreign output gaps. ${ }^{13}$ The inclusion of lagged inflation can be interpreted as implying the assumption of adaptive inflation expectations. ${ }^{14}$

The model is estimated using both headline inflation and two transformations of inflation as dependent variables, and also under alternative sets of weights for the global output gap. Table 2 reports the estimates of the coefficients $\beta$ and $\gamma$, including standard errors robust to autocorrelation and heteroscedasticity, also in order to deal with the documented changes in the conditional mean and variance of macroeconomic variables over time (see e.g. Stock and Watson, 2003).

The estimates indicate that, regardless of the weighting scheme used, the foreign output gap has no explanatory power for euro area headline inflation. This finding would be consistent with the expectation that an economy as large and closed as the euro area should be less sensitive to external spillovers. ${ }^{15}$ At the same time, these estimates lend little support to the traditional relationship between domestic output gaps and inflation, with the good empirical fit of the model mostly reflecting the strength of the auto-regressive component of inflation over the period

\footnotetext{
${ }^{13}$ Unit root tests suggest that inflation can be treated as $\mathrm{I}(0)$ over the sample period.

${ }^{14}$ Backward-looking Phillips curves are vulnerable to the Lucas critique and may be unsuitable to model the anti-inflationary credibility of central banks nowadays, but present some advantages in terms of empirical fit to the data. See Mishkin (1999) for a discussion.

${ }^{15}$ The estimates are fairly robust to the addition of oil price changes (as a proxy for supply shocks), with neither the magnitude nor the statistical significance of the coefficients of the domestic and foreign output gaps significantly changing.
} 
considered.

As mentioned earlier, it has been suggested that the explanatory power of global output gaps for inflation may be obscured by the declining trend of the latter (see e.g. Borio and Filardo, 2007). A possible approach to solve this problem consists of removing the trend from inflation by means of a statistical filter prior to the estimation of the Phillips curves.

Following this approach, we re-estimate (2) using the deviation of inflation from an estimated trend (obtained by means of the HodrickPrescott filter) as a dependent variable. However, also in this case the estimated coefficients of the foreign output gap computed under both trade and PPP weights remain statistically insignificant at the conventional significance levels (see row B in Table 2), indicating that using detrended inflation as our measure of price developments does not seem to alter the conclusion of a limited explanatory power of the global output gap.

Some authors have argued that the structural decline in inflation since the 1980s may have reflected breaks in the mean of nominal variables, mainly reflecting monetary policy regime shifts (see for instance Stock and Watson, 2003). Therefore, controlling for structural breaks in the mean of inflation may be a more appropriate method to account for the decline in inflation during the disinflation period than simply detrending it by means of statistical filters. This issue is relevant for our empirical analysis since the failure to account for structural breaks might undermine the stability of the backward-looking Phillips curves, ultimately invalidating the reliability of the estimated coefficients. ${ }^{16}$

In order to address these concerns, model (2) is re-estimated allowing for breaks in the mean of headline inflation:

$$
\boldsymbol{\pi}_{t+1}=c+\sum_{b k=1}^{N b k} c_{b k}+\sum_{j=0}^{3} \alpha_{\pi j} \boldsymbol{\pi}_{t-j}+\beta y_{t}^{h}+\gamma y_{t}^{f}+\varepsilon_{t+1}
$$

\footnotetext{
${ }^{16}$ However, it should be noted that the results of Hansen's (1992) LM test of individual parameter constancy show no evidence of instability in the estimated coefficients of the models for headline inflation reported in row A of Table 2.
} 
where $N b k$ denotes the number of mean breaks over the sample period. On the basis of the Altissimo and Corradi (2003) test for structural breaks, Corvoisier and Mojon (2005) identify one break in the mean of euro area consumer price inflation in mid-1985. ${ }^{17}$ The last row of Table 2 presents the estimated parameters $\beta$ and $\gamma$ from a model conditional on such break.

The main difference compared to the unconditional model for headline inflation is that the point estimates of the coefficients of the foreign output gaps (under both trade and PPP weights) are now larger and have become statistically significant at the conventional significance levels. Therefore, foreign output gaps seem to have explanatory power for inflation in the euro area, once we allow for a break in the mean of inflation in the mid-1980s.

Thus, the evidence from this set of estimated backward-Phillips curves seems rather inconclusive. Whether or not foreign capacity constraints have information content on euro area inflation seems to depend to a large extent on how we model the structural decline of inflation over the last few decades. A potential problem in this respect is that to the extent that the structural decline in inflation reflected a regime shift in monetary policy, the use of models of the inflation process that do not allow for forward-looking inflation expectations may not be appropriate. Thus, in the next section we consider a forward-looking specification that explicitly tackles the modelling problems stemming from the disinflation process.

\subsubsection{Forward-looking models as in Gerlach and Svensson (2003)}

The issue of how to model the behavior of euro area inflation since the 1980s in a forward-looking Phillips curve framework is extensively addressed in Gerlach and Svensson (2003), who specify the following model:

$$
\boldsymbol{\pi}_{t+1}=\boldsymbol{\pi}_{t+1, t}^{e}+\beta y_{t}^{h}+\alpha_{z} z_{t+1}+\varepsilon_{t+1}
$$

\footnotetext{
${ }^{17}$ Corvoisier and Mojon (2005) find evidence that most OECD countries experienced either one or two breaks in the mean of inflation between the early 1980s and mid-1990s
} 
in which $\boldsymbol{\pi}_{t+1, t}^{e}$ indicates the expectation in quarter $t$ of inflation in quarter $t+1$ and $z_{t+1}$ a vector of exogenous variables. In order to specify the expectation formation mechanism, Gerlach and Svensson (2003) argue that inflation expectations are influenced by the central bank's average inflation objective $\hat{\boldsymbol{\pi}}_{t}$. This objective is time-varying and "implicit" (i.e. not necessarily a formal target but rather the rate of inflation that policy makers consider as acceptable or desirable). In addition, inflation expectations are influenced by the current deviation of inflation from its objective:

$$
\boldsymbol{\pi}_{t+1, t}^{e}=\hat{\boldsymbol{\pi}}_{t+1}+\alpha_{\pi}\left(\boldsymbol{\pi}_{t}-\hat{\boldsymbol{\pi}}_{t}\right)
$$

where $\alpha_{\pi} \epsilon[0,1]$ is a parameter related to the degree of credibility of the central bank's commitment to its inflation objective. Thus, for $\alpha_{\pi}=0$ the commitment is fully credible and inflation expectations are not influenced by deviations of current inflation from its objective. By contrast, for $\alpha_{\pi}=1$ the central bank's commitment is not credible and the deviations of current inflation from its objective feed into expectations.

Gerlach and Svensson (2003) note that for most central banks in the euro area, "disinflating" meant to reduce inflation to levels similar to those prevailing in Germany. In order to achieve this objective, central banks aimed at achieving and maintaining the Bundesbank's "implicit" inflation objective. ${ }^{18}$ Given the initial inflation differential between Germany and most other euro area countries, the process of convergence in their objectives was gradual, though it gained momentum as the central banks' commitment became increasingly credible. The evolution of the euro area's average "implicit" inflation objective $\hat{\boldsymbol{\pi}}_{t}$ over time can then be described as follows:

$$
\hat{\boldsymbol{\pi}}_{t+1}-\hat{\boldsymbol{\pi}}_{t+1}^{b}=\boldsymbol{\lambda}^{t+1-t_{0}}\left(\hat{\boldsymbol{\pi}}_{t_{0}}-\hat{\boldsymbol{\pi}}_{t_{0}}^{b}\right)
$$

where $\hat{\boldsymbol{\pi}}_{t}^{b}$ denotes the Bundesbank's "implicit" inflation objective, $\boldsymbol{\lambda}$ the

\footnotetext{
${ }^{18}$ The Bundesbank never published an official inflation target. However, it used to release indications on its desired inflation rate under different labels (e.g. "unavoidable inflation" or "medium-term price assumption"). Gerlach and Svensson (2003) use these indicative figures to recontruct the Bundesbank's "implicit" inflation target.
} 
rate of convergence of the euro area inflation objective towards the Bundesbank's objective and $t_{0}$ is the date at which the process of inflation convergence started (1981:1 according to Gerlach and Svensson's dating). The combination of (4), (5) and (6) yields the empirical model to estimate:

$$
\begin{aligned}
\boldsymbol{\pi}_{t+1}-\hat{\boldsymbol{\pi}}_{t+1}^{b}= & \boldsymbol{\lambda}^{t+1-t_{0}}\left(\hat{\boldsymbol{\pi}}_{t_{0}}-\hat{\boldsymbol{\pi}}_{t_{0}}^{b}\right)+\alpha_{\pi}\left[\boldsymbol{\pi}_{t}-\hat{\boldsymbol{\pi}}_{t}^{b}-\boldsymbol{\lambda}^{t-t_{0}}\left(\hat{\boldsymbol{\pi}}_{t_{0}}-\hat{\boldsymbol{\pi}}_{t_{0}}^{b}\right)\right] \\
& +\beta y_{t}^{h}+\gamma y_{t}^{f}+\sum_{j=0}^{3} \alpha_{q j} \Delta q_{t+1-j}+\varepsilon_{t+1}
\end{aligned}
$$

where we have added the foreign output gap $y_{t}^{f}$ as an explanatory variable and we have replaced the vector of exogenous variables $z_{t+1}$ with the current and three lags of oil price inflation in order to control for the effect of energy price movements.

The results show that the coefficient of the domestic output gap is highly significant (see Table 3). By contrast, the coefficient of the foreign output gap is not statistically significant and has the wrong sign, regardless of the weighting scheme used for its computation. The coefficients of the other parameters are not too distant from the original estimates by Gerlach and Svensson (2003) over a shorter sample period.

\subsubsection{Summing up the main findings}

We can draw some lessons from this empirical exercise: first, the estimated standard backward-looking Phillips curves based on realised headline inflation fail to provide support to the claim that global output gaps feed into the inflation formation process. Second, detrending inflation by means of a statistical filter to remove its declining trend over the 1980s and 1990s does not alter this conclusion. By contrast, foreign output gaps seem to have explanatory power for the movements in inflation, once we control for one estimated break in its mean in the mid-1980s. Nevertheless, when we use a Phillips curve model allowing for forward-looking inflation expectations and a more sophisticated treatment of the shift in 
monetary policy and inflation regimes experienced during the disinflation period, the foreign output gap loses its explanatory power.

Thus, we conclude that the evidence from the euro area in support of the global output gap hypothesis is limited. In particular, this evidence is rather sensitive to the treatment of inflation to account for the disinflation period and, as noted by Ihrig et al. (2007) for other economies, very much dependent on the specification of the inflation model.

\subsection{Predicting future inflation using foreign variables}

So far we have considered the short-term effects of foreign output gaps on domestic price developments in the euro area. Yet, the full impact of global developments on euro area inflation may emerge only over time. This section investigates whether changes in foreign cyclical conditions contain statistically reliable information on future inflation in the euro area.

The analysis is based on an econometric approach applied by Hamilton and Kim (2002) to assess the usefulness of the yield spread to predict future economic growth. The empirical exercise consists of regressing future domestic inflation over different forecast horizons on a set of variables comprising current and lagged values of domestic inflation together with the measure of the foreign output gap $\mathbf{y}_{t}^{f}$ under consideration:

$$
\boldsymbol{\pi}_{t}^{k}=c+\sum_{j=1}^{n} \alpha_{\pi j} \boldsymbol{\pi}_{t-j}^{1}+\gamma y_{t}^{f}+\varepsilon_{t}
$$

where $\boldsymbol{\pi}_{t}^{k}$ is the annualised cumulative rate of inflation over the next $k$ quarters in the euro area:

$$
\boldsymbol{\pi}_{t}^{k}=(4 / k) *\left(p_{t+k}-p_{t}\right)
$$

Current and lagged developments in domestic prices are included in (8) because past inflation has historically proven useful to predict its future values. Following Hamilton and $\operatorname{Kim}$ (2002), $n$ is set to 4 . As in the previous empirical exercise, we are interested in analysing the information content of measures of foreign output gaps computed under the two 
alternative weighting schemes.

The results for the full sample period show that, regardless of the weighting scheme used, the foreign output gaps fail to provide statistically significant information on future price developments up to two years (Table 4). However, the coefficient of the foreign output gaps is statistically significant for inflation three years ahead and for inflation four years ahead (though in the former case only at the $10 \%$ significance level), suggesting that global capacity constraints exhibit some predictive power in the medium term.

These results prove though not robust to changes in the sample period. Indeed, when the estimation sample is shortened so as to start at the end of 1985, the foreign output gap has no longer predictive power for inflation three years ahead and it helps to predict inflation at the four year horizon only when it is computed using trade weights.

Overall, the results of this analysis suggest that foreign capacity constraints have limited predictive power for future inflation in the euro area. ${ }^{19}$ Foreign output gaps provide additional information - i.e. beyond that contained in current and lagged inflation - on future price developments only at relatively long forecast horizons (between three and four years ahead), but these results are rather sensitive to the choice of sample period and weighting scheme.

\section{Conclusions}

There is increasing interest in understanding the channels through which globalisation has influenced the inflation process in recent decades. The reason for such interest has been clearly spelled out by the President of the Federal Reserve Bank of Dallas and member of the Federal Open Market Committee Richard Fisher (2005), :

"One cannot make monetary policy without being aware of the forces of globalization acting upon our economy".

\footnotetext{
${ }^{19}$ To the contrary, Ciccarelli and Mojon (2005) show that measures of global inflation have reliable predictive power for future domestic inflation in a number of euro area countries.
} 
Some authors and policy-makers have recently suggested that one of the main channels through which globalisation has affected the inflation process is by increasing the sensitivity of domestic price developments to foreign macroeconomic conditions, particularly capacity constraints abroad (see e.g. BIS, 2005; Fisher, 2005; Helbling et al. 2006; and Borio and Filardo, 2007). This proposition has been accompanied by the recommendation that central banks aiming to maintain price stability should pay close attention to developments in global rather than domestic output gaps. Both the original proposition and the policy prescription have been popularised by newspapers commanding wide international circulation, such as The Economist and Business Week.

This paper has aimed to provide fresh empirical evidence on this hypothesis for the euro area. In order to do so, we have estimated different specifications of Phillips curves augmented by global output gaps and also tested whether these variables have leading indicator properties for domestic inflation. We find very limited evidence that measures of global capacity constraints have either explanatory or predictive power for domestic consumer price inflation in the euro area.

The key policy implication of our findings is that, while central bankers should certainly be alert to global monetary, financial and real developments and their implications for price stability at home, the prescription by the "global output gap hypothesis" that they should specifically react to developments in global output gaps does not seem to be justified.

\section{References}

[1] Altissimo, F. and V. Corradi (2003): "Strong rules for detecting the number of breaks in a time series", Journal of Econometrics, 117, 207-244.

[2] Ball, L. (2006). "Has globalization changed inflation", NBER Working Paper No. 12687.

[3] Bank for International Settlements (BIS) (2005). 75th Annual Report, 1 April 2004 - 31 March 2005, Basel: BIS, June. 
[4] Baxter, M. and M.A. Kouparitsas (2005). "Determinants of business cycle comovement: A robust analysis", Journal of Monetary Economics, 52(1), 113-157.

[5] Bernanke, B. (2007). "Globalization and monetary policy", Speech at the $4^{\text {th }}$ Economic Summit, Stanford Institute for Economic Policy Research, Stanford, CA, March.

[6] Borio, C. and A. Filardo (2007). "Globalisation and inflation: New cross-country evidence on the global determinants of domestic inflation", BIS Working Papers No. 227.

[7] Business Week (2006). "A narrow window on the world", 5 June.

[8] Ciccarelli, M. and Mojon, B. (2005). "Global inflation", European Central Bank Working Paper No. 537.

[9] Corvoisier, S. and Mojon, B. (2005). "Breaks in the mean of inflation: How they happen and what to do with them", European Central Bank Working Paper No. 451.

[10] Dees, S., di Mauro, F., Pesaran, M.H. and Smith, L.V. (2007). "Exploring the international linkages of the euro area: A Global VAR analysis", Journal of Applied Econometrics, 22(1), 1-38.

[11] Fagan, G., Henry, F. and R. Mestre (2005). "An area-wide model (AWM) for the euro area", Economic Modelling, 22 (1), 39-59.

[12] Fisher, R.W. (2005). "Globalization and monetary policy", Warren and Anita Manshel lecture in American foreign policy, Harvard University, 3 November.

[13] Forbes, K.J. and Chinn, M.D. (2004). "A decomposition of global linkages in financial markets over time", The Review of Economics and Statistics, 86 (3), 705-722.

[14] Gamber, E.N. and J.H. Hung (2001). "Has the rise in globalization reduced U.S. inflation in the 1990s?", Economic Inquiry, 39(1), 5873. 
[15] Garner, A. C. (1994). "Capacity utilization and US inflation", Federal Reserve Bank of Kansas City Economic Review, 79 (4), 5-21.

[16] Gerlach S. and L.E.O. Svensson (2003). "Money and inflation in the euro area: A case for monetary indicators?", Journal of Monetary Economics 50(8), 1649-1672.

[17] González-Páramo, J.M. (2007). "Globalisation and monetary policy", Lecture at Suomen Pankki, Helsinski, 15 March.

[18] Greenspan, A. (2005). "Economic outlook", Testimony before the Joint Economic Committee, U.S. Congress, 3 November.

[19] Gulde, A.M. and M. Schulze-Ghattas (1993), Purchasing power parity based weights for the World Economic Outlook, IMF Staff Studies for the WEO, December.

[20] Hamilton, J. D., and Kim, D. H. (2002). "A reexamination of the predictability of economic activity using the yield spread", Journal of Money, Credit and Banking, 34(2), 340-360.

[21] Hansen, B.E. (1992). "Testing for parameter instability in linear models", Journal of Policy Modelling, 14(4), 517-533.

[22] Helbling, T., Jaumotte, F. and M. Sommer (2006). "How has globalization affected inflation", Chapter III, in: IMF World Economic Outlook, Globalization and Inflation, Washington: IMF, April.

[23] Ihrig, J., Kamin, S., Lindner, D. and J. Marquez (2007). "Some simple tests of the globalization and inflation hypothesis", Board of Governors of the Federal Reserve System, International Finance Discussion Paper No. 891.

[24] Kaiser, R. and A. Maravall (1999). "Estimation of the Business Cycle: A Modified Hodrick-Prescott Filter", Spanish Economic Review, $1(2), 175-206$.

[25] Kohn, D.L. (2005). "Globalization, inflation and monetary policy", Remarks at the James R. Wilson lecture series, The College of Wooster, Ohio, 11 October. 
[26] Kohn, D.L. (2006). "The effects of globalization on inflation and their implications for monetary policy", Remarks at the Federal Reserve Bank of Boston's 51st Economic Conference, Chatham, Massachussetts, 16 June.

[27] Mishkin, F.S. (1999). "Policy rules for inflation targeting: Comment", in J.B. Taylor (ed.), Monetary Policy Rules, NBER Conference Report series. Chicago and London: University of Chicago Press, 247-253.

[28] Orr, J.A (1994). "Has excess capacity abroad reduced US inflationary pressures", FRBNY Quarterly Review, Summer-Fall, 101-105.

[29] Pain, N., Koske, I. and M. Sollie (2006). "Globalisation and inflation in the OECD economies", OECD Economics Department Working Paper No. 524.

[30] Papademos, L. (2006). "Monetary policy in a changing world: Commitment, strategy and credibility", Speech at the $4^{\text {th }}$ Conference of the International Research Forum on Monetary Policy, Federal Reserve Board, Washington, D.C., 1-2 December.

[31] Pesaran, M.H., Schuermann, T. and S.M. Weiner (2004). "Modelling regional interdependencies using a global error-correcting macroeconometric model", Journal of Business 85 Economic Statistics, 22 (2), 129-162.

[32] Roberts, J.M. (2006). "Monetary Policy and Inflation Dynamics", International Journal of Central Banking, September, 2(3), 193-230.

[33] Rudebusch, G.D. and L.E.O. Svensson (1999). "Policy rules for inflation targeting", in J.B. Taylor (ed.), Monetary Policy Rules, NBER Conference Report series. Chicago and London: University of Chicago Press, 203-246.

[34] Rudebusch, G.D. and L.E.O. Svensson (2002). "Eurosystem monetary targeting", European Economic Review, 46(3), 417-442. 
[35] Stock, J.H. and M.W. Watson (2003). "Has the business cycle changed and why?", in Gertler, M and K.S. Rogoff (eds.), NBER Macroeconomics Annual 2002, Cambridge and London: The MIT Press, 159-218.

[36] The Economist (2005). "A foreign affair", Economics Focus, 20 October.

[37] Tootell, G.M.B. (1998). "Globalization and US inflation", New England Economic Review, July/August, 21-33.

[38] Yellen, J.L. (2006). "Monetary policy in a global environment", Speech at "The euro and the dollar in a globalized economy conference", U.C. Santa Cruz, Santa Cruz, CA, 27 May.

[39] Woodford, M. (2007). "Globalization and monetary control", NBER Working Paper No. 13329.

[40] Wynne, M.A. and E.K. Kersting (2007). "Openness and inflation", Staff Papers Federal Reserve Bank of Dallas No. 2, April.

[41] Wynne, M.A. and G.R. Solomon (2007). "Obstacles to measuring output gaps", Economic Letter - Insights from the Federal Reserve Bank of Dallas 2(3), March. 
Table 1: Shares of variance of consumer price inflation measures explained by alternative measures of external output gaps

\begin{tabular}{r|cc|c|c}
\hline \hline \multirow{2}{*}{ Inflation measure } & \multicolumn{2}{|c|}{ Headline } & \multicolumn{2}{c}{ Detrended } \\
\cline { 2 - 5 } & $79: 1-03: 4$ & $85: 4-03: 4$ & $79: 1-03: 4$ & $85: 4-03: 4$ \\
\hline & & & & \\
Foreign output gap & & & & \\
Trade weights & 0.00 & 0.00 & 0.00 & 0.01 \\
PPP weights & 0.00 & 0.01 & 0.00 & 0.00 \\
& & & & \\
Domestic output gap & 0.03 & 0.13 & 0.07 & 0.12 \\
\hline \hline
\end{tabular}

Notes: Detrended inflation is computed by running the Hodrick-Prescott filter on annualised quarterly consumer price inflation. 
Table 2: Estimates of selected parameters of backward-looking Phillips curves (as in Rudebusch and Svensson, 1999, 2002) augmented by foreign output gaps

\begin{tabular}{|c|c|c|c|c|c|c|}
\hline \multirow[b]{3}{*}{ Dependent variable } & \multicolumn{6}{|c|}{ 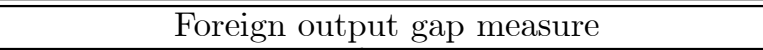 } \\
\hline & \multicolumn{3}{|c|}{ Trade weights } & \multicolumn{3}{|c|}{ PPP weights } \\
\hline & $\beta$ & $\gamma$ & $R_{a d j}^{2}$ & $\beta$ & $\gamma$ & $R_{a d j}^{2}$ \\
\hline (A) Headline inflation & $\begin{array}{c}0.05 \\
(0.09)\end{array}$ & $\begin{array}{c}0.12 \\
(0.12)\end{array}$ & 0.90 & $\begin{array}{c}0.08 \\
(0.09)\end{array}$ & $\begin{array}{c}0.09 \\
(0.12)\end{array}$ & 0.90 \\
\hline (B) Detrended inflation & $\begin{array}{c}0.13 \\
(0.09)\end{array}$ & $\begin{array}{c}0.03 \\
(0.09)\end{array}$ & 0.16 & $\begin{array}{c}0.14 \\
(0.09)\end{array}$ & $\begin{array}{c}0.01 \\
(0.10)\end{array}$ & 0.16 \\
\hline $\begin{array}{l}\text { (C) Inflation adjusted for } \\
\text { mean breaks }\end{array}$ & $\begin{array}{c}0.10 \\
(0.11)\end{array}$ & $\begin{array}{l}0.19^{*} \\
(0.11)\end{array}$ & 0.44 & $\begin{array}{c}0.14 \\
(0.11)\end{array}$ & $\begin{array}{r}0.20^{* *} \\
(0.10)\end{array}$ & 0.48 \\
\hline
\end{tabular}

Notes: $* * *, * *$ and $*$ denote statistically significant at the $1 \%, 5 \%$ and $10 \%$ critical levels, respectively. Equations estimated with OLS using the Newey-West covariance estimator (with truncation lag set to 3 ) over the sample period 1979.1 to 2003.3. Detrended inflation is computed by running the Hodrick-Prescott filter on annualised quarterly consumer price inflation. Inflation adjusted for mean breaks is based on the estimated break by Corvoisier and Mojon (2005). 
Table 3: Estimates of selected parameters of Phillips curves as in Gerlach and Svensson (2003) augmented by foreign output gaps

\begin{tabular}{l|c|c}
\hline \hline \multirow{2}{*}{$\beta$} & \multicolumn{2}{|c}{ Foreign output gap } \\
\cline { 2 - 3 }$\beta$ & Trade weights & PPP weights \\
\hline \multirow{4}{*}{$\gamma$} & $0.31^{* *}$ & $0.29^{* *}$ \\
& $(0.15)$ & $(0.14)$ \\
& -0.11 & -0.11 \\
$\lambda$ & $(0.09)$ & $(0.09)$ \\
& $0.96^{* * *}$ & $0.96^{* * *}$ \\
& $(0.01)$ & $(0.01)$ \\
$\hat{\pi}_{t_{0}}-\hat{\pi}_{t_{0}}^{b}$ & $0.06^{* * *}$ & $0.06^{* * *}$ \\
& $(0.01)$ & $(0.01)$ \\
$\alpha_{\pi}$ & $0.46^{* * *}$ & $0.45^{* * *}$ \\
& $(0.15)$ & $(0.15)$ \\
$R_{a d j}^{2}$ & 0.82 & 0.82 \\
\hline \hline
\end{tabular}

Notes: $* * *, * *$ and $*$ denote statistically significant at the $1 \%, 5 \%$ and $10 \%$ critical levels, respectively. Equations are estimated with NLS using the Newey-West covariance estimator (with truncation lag set to 3) over the sample period 1981.2 to 2003.3 . 
Table 4: Testing the information content of foreign output gap for future consumer price inflation

\begin{tabular}{|c|c|c|c|c|c|c|c|c|}
\hline & $\overline{\mathrm{k}=}$ & 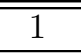 & 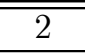 & 3 & $\begin{array}{l}4 \\
\end{array}$ & 8 & 12 & 18 \\
\hline \multicolumn{9}{|c|}{ (A) Sample 1979:1 - 2003:4-k } \\
\hline Trade weights & $\begin{array}{c}\gamma \\
R_{a d j}^{2}\end{array}$ & $\begin{array}{l}0.14 \\
0.90\end{array}$ & $\begin{array}{l}0.12 \\
0.93\end{array}$ & $\begin{array}{l}0.14 \\
0.93\end{array}$ & $\begin{array}{l}0.18 \\
0.92\end{array}$ & $\begin{array}{l}0.19 \\
0.88\end{array}$ & $\begin{array}{r}0.26^{*} \\
0.83\end{array}$ & $\begin{array}{c}0.39 * * * \\
0.80\end{array}$ \\
\hline PPP weights & $\begin{array}{c}\gamma \\
R_{a d j}^{2}\end{array}$ & $\begin{array}{l}0.10 \\
0.90\end{array}$ & $\begin{array}{l}0.09 \\
0.92\end{array}$ & $\begin{array}{l}0.11 \\
0.93\end{array}$ & $\begin{array}{l}0.13 \\
0.92\end{array}$ & $\begin{array}{l}0.16 \\
0.88\end{array}$ & $\begin{array}{r}0.24^{*} \\
0.83\end{array}$ & $\begin{array}{c}0.35^{* * *} \\
0.80\end{array}$ \\
\hline \multicolumn{9}{|c|}{ (B) Sample 1985:4 - 2003:4-k } \\
\hline Trade weights & $\begin{array}{c}\gamma \\
R_{a d j}^{2}\end{array}$ & $\begin{array}{l}0.14 \\
0.52\end{array}$ & $\begin{array}{l}0.14 \\
0.64\end{array}$ & $\begin{array}{l}0.16 \\
0.67\end{array}$ & $\begin{array}{l}0.19 \\
0.63\end{array}$ & $\begin{array}{l}0.21 \\
0.55\end{array}$ & $\begin{array}{l}0.24 \\
0.40\end{array}$ & $\begin{array}{c}0.35^{* *} \\
0.31\end{array}$ \\
\hline PPP weights & $\begin{array}{c}\gamma \\
R_{a d j}^{2}\end{array}$ & $\begin{array}{l}0.05 \\
0.52\end{array}$ & $\begin{array}{l}0.06 \\
0.64\end{array}$ & $\begin{array}{l}0.08 \\
0.66\end{array}$ & $\begin{array}{l}0.10 \\
0.62\end{array}$ & $\begin{array}{l}0.16 \\
0.54\end{array}$ & $\begin{array}{l}0.19 \\
0.38\end{array}$ & $\begin{array}{l}0.27 \\
0.28\end{array}$ \\
\hline
\end{tabular}

Notes: $* * *, * *$ and $*$ denote statistically significant at the $1 \%, 5 \%$ and $10 \%$ critical levels, respectively. Equations corresponding to column k are estimated with OLS using the Newey-West covariance estimator (with truncation lag set to 3 ). 
Figure 1. Euro area domestic and foreign output gaps (as a percentage of potential output)

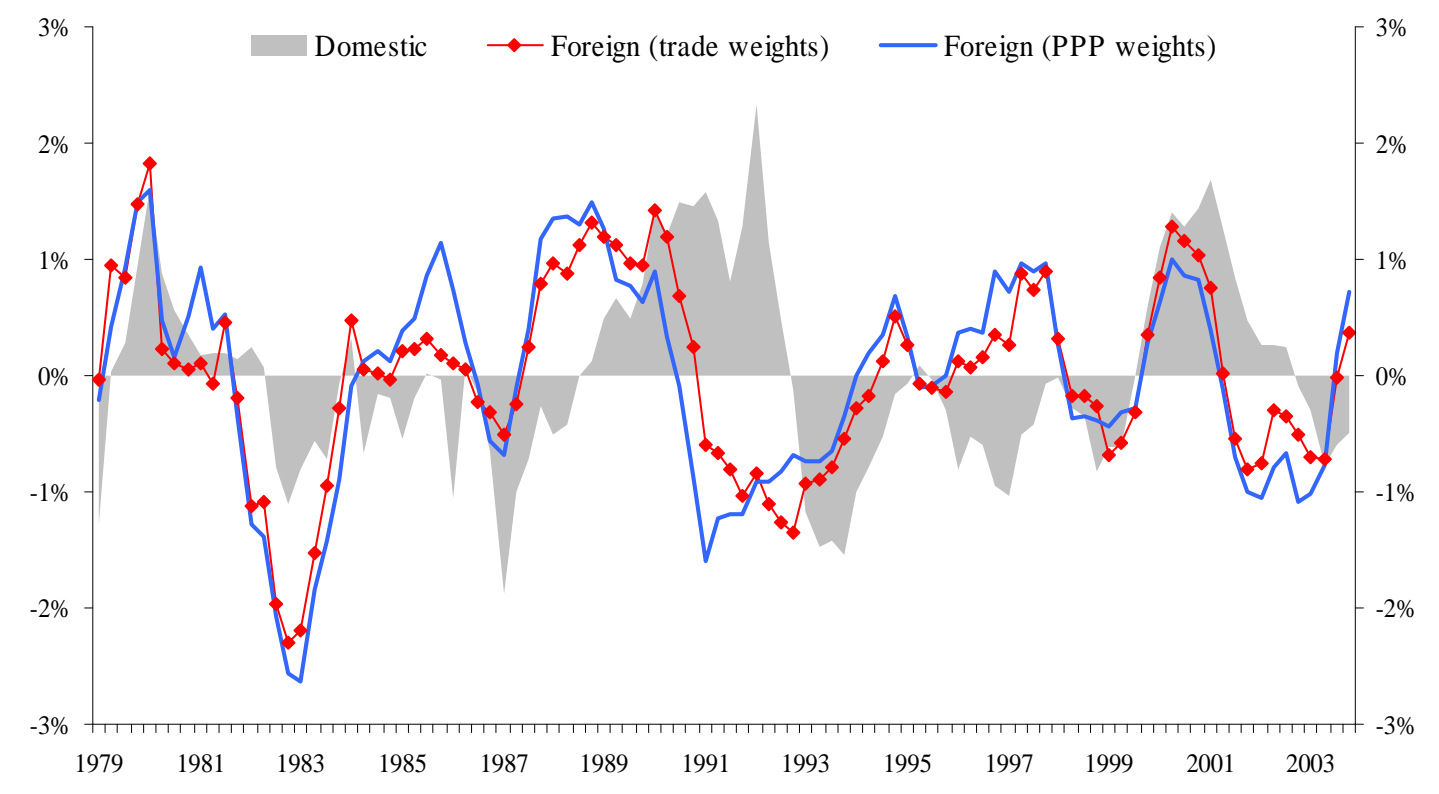

Note: The output gaps are percentage deviations of real GDP from their potential levels, as estimated using the Hodrick-Prescott filter. 
Figure 2. Inflation measures (percentage points)

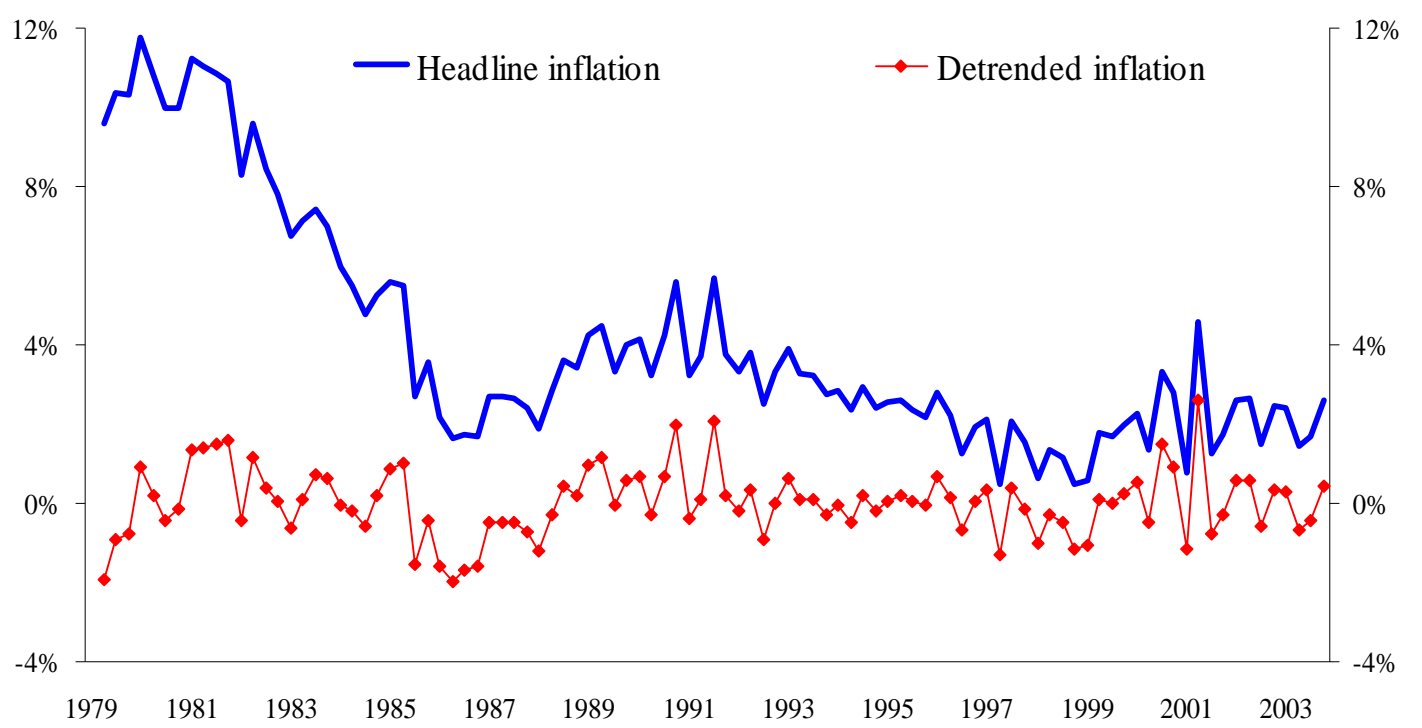

Notes: Detrended inflation is computed by running the Hodrick-Prescott filter on annualised quarterly headline consumer price inflation. 